\title{
Pengaruh Kecerdasan Emosional dan Komunikasi Interpersonal terhadap Kinerja Karyawan PT. PLN (Persero) Cabang Ternate
}

\author{
Utari Sofyan $^{a}$, Ruslan A. Kamis ${ }^{\mathrm{b}}$, Muhammad Thahrim ${ }^{\mathrm{c}}$, Rahmat Sabuharid \\ anniversitas Khairun Ternate, tryutariscada@gmail.com \\ bUniversitas Khairun Ternate, ruslankamis@unkhair.ac.id \\ 'Universitas Khairun Ternate, thahrim@unkhair.ac.id \\ dUniversitas Khairun Ternate, rahmat.sabuhari@unkhair.ac.id
}

\begin{abstract}
A b s trak
Karyawan dituntut mampu memuaskan pelanggan dalam ketersedian listrik dan juga kepuasan dalam pelayanan yang bersifat administratif. Tujuan penelitian ini adalah untuk mengetahui dan menguji secara parsial pengaruh kecerdasan emosional dan komunikasi interpersonal terhadap kinerja karyawan dan juga mengujinya secara simultan pada karyawan PT. PLN (Persero) Cabang Ternate. Jumlah sampel penelitian adalah sebanyak 57 orang. Alat uji yang digunakan adalah analisis regresi linear berganda dengan menggunakan statistical package for social scientists (SPSS) sebagai alat uji statistik. Hasil penelitian secara parsial menunjukan bahwa kecerdasan emosional tidak berpengaruh terhadap kinerja karyawan sedangkan komunikasi interpersonal memiliki pengaruh yang signifikan terhadap kinerja karyawan. Hasil penelitian juga membuktikan secara simultan bahwa kecerdasan emosional dan komunikasi interpersonal memiliki pengaruh yang signifikan terhadap kinerja karyawan.
\end{abstract}

Kata Kunci: Kecerdasan Emosional, Komunikasi Interpersonal, Kinerja Karyawan.

\section{A b s t r a c t}

Employees are required to be able to satisfy customers in the availability of electricity and also satisfaction in administrative services. The purpose of this study was to determine and partially test the effect of emotional intelligence and interpersonal communication on employee performance and test it simultaneously on employees of PT. PLN (Persero) Ternate Branch. The number of research samples was 57 people. The test tool used is multiple linear regression analysis using the statistical package for social scientists (SPSS) as a statistical test tool. The study results partially show that emotional intelligence does not affect employee performance while interpersonal communication significantly influences employee performance. The survey results also prove simultaneously that emotional intelligence and interpersonal communication substantially impact employee performance.

Keywords: Emotional intelligence, interpersonal communication, employee performance.

\section{Pendahuluan}

Dewasa ini terlihat jelas ketimpangan produk pelayanan yang dihasilkan organisasi publik yakni organisasi yang dikuasai dan dikelola pemerintah dan organisasi privat atau swasta. Dimana pelayanan publik yang diberikan swasta lebih menitik beratkan pada konsumen atau pelanggan lebih kuat sedangkan posisi konsumen atau pelanggan menjadi lemah karena tingginya intervensi dan kontrol atas pelayanan yang diberikan. Pelayanan kepada masyarakat merupakan suatu area transaksi yang paling nyata dan intensif antara pemerintah dengan masyarakat. Interaksi yang aktif antara pemberi dan penerima layanan merupakan bagian penting dari proses membangun partisipasi dan akuntabilitas publik. 
Jaminan kualitas pelayanan publik sangat diharapkan oleh masyarakat. Pemberian pelayanan yang memenuhi standar yang telah ditetapkan memang menjadi bagian yang perlu dicermati.

Perusahaan Listrik Negara Kota Ternate merupakan salah satu organisasi publik sebagai perwujudan komitmen dan upaya pemerintah untuk memenuhi hak dasar warga Negaranya dalam bidang kesejahteraan melalui pemenuhan kebutuhan masyarakat pada bidang penyediaan tenaga listrik. Dalam rangka penghematan dan efisiensi penggunaan listrik, pemerintah dalam hal ini mengambil kebijakan, salah satunya pemadaman listrik bergilir. Pemadaman listrik bergilir ini dianggap mengganggu kenyamanan masyarakat sendiri. Berita-berita dimedia massa baik elektronik maupun non elektronik mengabarkan bahwa sejak tahun 2007 sering dilakukan pemadaman bergilir. Beberapa waktu lalu informasi pemadaman dikabarkan lewat media Koran, namun kadang pemadaman dilakukan tanpa pemberitahuan, pemadaman ini berkisar dari 4 sampai 8 jam sehari.

Masyarakat menganggap bahwa pemadaman ini merugikan mereka, sehingga masyarakat menilai bahwa pelayanan PLN menjadi buruk. Hal ini dianggap mengabaikan KEPMENPAN Nomor 81 tahun 1993 serta sendi-sendi dari pelayanan prima (Yusni, 2015). PLN sebagai penghasil listrik satu-satunya, pemegang monopoli pasar dimungkinkan untuk bertindak sesuai dengan kemauan mereka, namun PLN merupakan organisasi yang berada dibawah pengawasan pemerintah dituntut mampu memberikan layanan sesuai dengan perkembangan zaman saat ini, mulai dari ketersedian karyawan yang memadai dan kompeten, sistem yang efektif hingga sarana dan prasarana mampu berfungsi menunjang pelayanan yang memuaskan (Rusdi, Langkai, dan Tangkau, 2020). Karyawan PLN dituntut mampu memuaskan pelanggan bukan hanya dalam ketersedian listrik tapi juga kepuasan dalam pelayanan yang bersifat administratif. Hasil pengamatan bahwa, sikap petugas pelayanan sering mendapat sorotan. Ketika pelanggan melakukan komplain, pihak pemberi layanan tidak memberikan pelayanan yang maksimal. PLN dinilai kurang tanggap dan lambat dalam menyelesaikan keluhan dan masalah yang pada akhirnya membuat masyarakat kecewa. Pelayanan pun mendapat nilai negatif dari masyarakat dan menimbulkan ketidakpuasaan bagi masyarakat selaku pelanggan PT PLN (Persero). Pelayanan publik dapat diartikan sebagai aktifitas seseorang, kelompok dan atau organisasi penyelenggaraan pemerintah baik secara langsung maupun tidak langsung menyediakan barang dan jasa untuk memenuhi kebutuhan warga negara atau masyarakat (Pasolong, 2010; Putra, 2012; Putri, 2018).

Kinerja yang optimal dapat didukung oleh kecerdasan emosional yang meliputi kemampuan untuk memotivasi diri dan bertahan menghadapi frustrasi, mengendalikan dorongan hati dan tidak melebih-lebihkan kesenangan, mengatur suasana hati dan menjaga beban stres agar tidak melumpuhkan kemampuan berfikir dan berempati (Goleman, 2009). Selanjutnya Widyastini (2003), mengatakan bahwa secara khusus para pemimpin perusahaan membutuhkan kecerdasan emosional yang tinggi karena mereka mewakili organisasi dan berinteraksi dengan banyak orang baik didalam maupun diluar organisasi serta berperan penting dalam membentuk moral dan disiplin para pegawainya. 
Kecerdasan emosional juga dapat berkontribusi terhadap kinerja seseorang untuk memungkinkan seseorang dapat mengatur emosi mereka dalam rangka mengatasi stres dan melakukan dengan baik dibawah tekanan, dan juga dapat membantu seseorang untuk beradaptasi dengan perubahan organisasi. Pendapat yang sama dari hasil penelitian yang dilakukan Alkahtani (2013), ada pengaruh kecerdasan emosional terhadap kinerja. Hasil penelitian terdahulu Supriadi dan Sefnedi (2017), dan Sulistio, Assa, dan Herdiansyah, (2016), menemukan kecerdasan emosional berpengaruh positif dan signifikan terhadap kinerja. Namun kecerdasan emosional berpengaruh negatif dan tidak signifikan terhadap kinerja sejalan dengan penelitian yang dilakukan oleh Christina dan Samanta (2016), menunjukkan bahwa kecerdasan emosional tidak memberikan pengaruh terhadap aktifitas sumber daya manusia yaitu rekruitmen dan komposisi kelompok kerja. Secara empiris pengaruh kecerdasan emosional terhadap kinerja sangat beragam sehingga peneliti tertarik untuk melakukan pengujian kembali untuk memperoleh kejelasan pengaruh dari variabel tersebut.

Selain kecerdasan emosional komunikasi yang efektif antara atasan dan bawahan maupun rekan sejawat juga diperlukan untuk menghasilkan kinerja yang baik. Menurut Robbins dan Judge (2013), dengan komunikasi organisasi dapat memelihara motivasi karyawan dengan memberikan penjelasan kepada karyawan tentang apa yang harus dilakukan, seberapa baik mereka mengerjakannya dan apa yang dapat dilakukan karyawan untuk meningkatkan kinerjanya jika sedang berada dibawah standar.

Komunikasi yang tidak baik mempunyai dampak yang luas terhadap kehidupan organisasi, misalnya konflik antar karyawan, dan sebaliknya komunikasi yang baik dapat meningkatkan saling pengertian, kerja sama dan juga kepuasan kerja diantara karyawan dan pimpinan. Karyawan yang mempunyai kemampuan komunikasi yang baik akan mampu memperoleh dan mengembangkan tugas yang diembannya, sehingga tingkat kinerja karyawan menjadi semakin baik. Artinya bahwa komunikasi interpersonal memiliki pengaruh yang positif dan signifikan terhadap kinerja karyawan (Rusmalinda dan Saputri 2016; dan Krisnanto dan Pratomo, 2017).

Berdasarkan uraian fenomena tersebut dan adanya perbedaan dalam penelitian menyebabkan peneliti ingin melakukan penelitian untuk mengkaji lebih mendalam tentang pengaruh kecerdasan emosional dan komunikasi interpersonal terhadap kinerja karyawan PT. PLN (Persero) Cabang Ternate. Berdasarkan latar belakang yang telah diuraikan diatas, maka penulis ingin mengkaji melalui analisis pengaruh langsung secara parsial dan simultan kecerdasan emosional, dan komunkasi interpersonal terhadap kinerja karyawan.

\section{Landasan Teori}

\subsection{Pengembangan Hipotesis Penelitian}

\subsubsection{Pengaruh Kecerdasan Emosional terhadap Kinerja Karyawan}

Kinerja selalu menjadi isu aktual dalam organisasi apapun bentuknya, karena kinerja merupakan kunci atau keberhasilan organisasi. Selain itu, kinerja juga merupakan sumber daya manusia yang harus direncanakan, dikelola, dan dievaluasi secara baik dan benar. 
Menurut Salovey dan Mayer (1990), kecerdasan emosional adalah seperangkat kemampuan sosial individu atau keterampilan untuk memantau, diskriminasi, dan mengendalikan diri dan emosi untuk mengatur cara berpikir serta tindakan seseorang.

Sedangkan kinerja pegawai menurut Mangkunegara (2000), adalah hasil kerja secara kualitas dan kuantitas yang dicapai oleh seseorang pegawai dalam melaksanakan tugasnya sesuai dengan tanggung jawab yang diberikan kepadanya. Jadi, hasil kerja yang hendak dicapai oleh seorang pegawai sangat memerlukan kecerdasan emosional. Karena itu, pegawai dalam melaksanakan tugas ditempat kerja, harus mampu mengelola emosinya dan juga emosi orang lain. Ini berarti mencapai hasil kerja juga membutuhkan kecerdasan emosional. Karena itu Goleman mengatakan, bahwa untuk mencapai kesuksesan dalam dunia kerja bukan hanya kemampuan kognitif (cognitive intelligence) saja yang dibutuhkan tetapi juga kemampuan emosional (emotional intelligence). Uraian diatas menunjukkan bahwa, kecerdasan emosional dapat mempengaruhi kinerja pegawai (Supriadi dan Sefnedi, 2017; Sulistio, Assa, dan Herdiansyah, 2016; dan Sholiha, Sunaryo, dan Priyono, 2017).

Berdasarkan uraian diatas, maka dapat dirumuskan hipotesis sebagai berikut:

H1. Kecerdasan emosional berpengaruh positif dan signifikan terhadap kinerja pegawai.

\subsubsection{Pengaruh Komunikasi Interpersonal Terhadap Kinerja Pegawai}

Menurut Daft (2006), komunikasi adalah proses dimana informasi ditukar dan dipahami oleh dua orang atau lebih, biasanya dengan maksud untuk memotivasi atau mempengaruhi perilaku. Definisi tersebut merupakan komunikasi antar pribadi. Sedangkan menurut Mulyana (2014), komunikasi antar pribadi atau komunikasi interpersonal adalah komunikasi antara orang-orang secara tatap muka yang memungkinkan setiap pesertanya menangkap reaksi orang lain secara langsung. Kedua definisi ini menunjukan bahwa, orang-orang ditempat kerja pasti melakukan komunikasi baik secara lisan maupun tulisan. Dengan demikian, komunikasi interpersonal harus memenuhi unsur: keterbukaan (openness), empati (empathy), sikap mendukung (supportiveness), sikap positif (positiveness), dan kesetaraan (equality), sehingga kinerja atau hasil kerja dapat dicapai sesuai dengan keinginan organisasi.

Uraian diatas menujukan bahwa komunikasi antar pergawai ditempat kerja akan menghasilkan hubungan antar sesama pegawai dan hubungan pegawai dengan atasan terkait dengan berbagai tugas, akan menghasilkan sesuatu yang bermanfaat bagi pegawai dan juga organisasi. Artinya tindakan atau komukasi seluruh pegawai akan memberikan kontribusi terhadap tujuan yang telah ditetapkan. Hal ini sebagaimana konsep kinerja menurut Amstrong (2010), kinerja adalah perilaku dan hasil, dimana perilaku yang bersumber dari seorang individu ditranformasikan menjadi suatu tindakan dan selain itu, bahwasanya perilaku juga merupakan hasil yang dihasilkan secara psikis dan fisik untuk menghasilkan suatu hasil (performance). Hasil penelitian yang menunjukan bahwa komunikasi interpersonal berpengaruh positif dan signifikan terhadap kinerja pegawai. Dalam penelitian tersebut dijelaskan juga bahwa semakin baik komunikasi interpersonal pegawai yang terjalin didalam organisasi, maka akan semakin tinggi kinerja pegawai (Rusmalinda dan Saputri, 2016; Aziz dan Suryadi, 2017; dan (Wahyuni dan Irfani, 2018). 
Dengan demikian maka dapat dirumuskan hipotesis sebagai berikut:

H2. Komunikasi interpersonal berpengaruh positif dan signifikan terhadap kinerja karyawan

H3. Kecerdasan emosional dan komunikasi interpersonal berpengaruh positif dan signifikan secara simultan terhadap kinerja karyawan

Berdasarkan uraian teori dan pengembangan hipotesis maka dapat dibuat gambar kerangka konsep penelitian sebagai berikut:

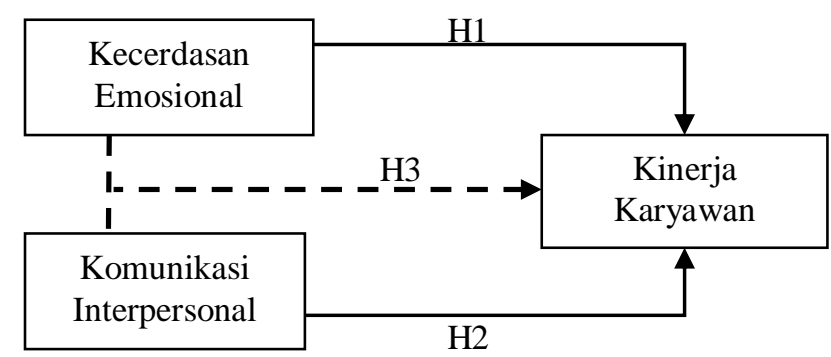

\section{Gambar 1. Model Pengaruh antar Variabel dan Hipotesis}

Sumber: diolah dari teori dan penelitian terdahulu

\section{Metode}

\subsection{Populasi dan Sampel}

Populasi dalam penelitian ini adalah karyawan tetap pada PT. PLN (Persero) Kota Ternate. Populasi yang diambil oleh peneliti adalah 57 orang. Menurut Arikunto (2010), jika subjeknya kurang dari 100 orang sebaiknya diambil semuanya, jika subjeknya besar atau lebih dari 100 orang dapat diambil $10-15 \%$ atau $20-25 \%$ atau lebih. Karena itu, sampel dalam penelitian ini seluruh populasi yaitu 57 karyawan sehingga disebut sebagai penelitian sensus.

\subsection{Metode Pengumpulan Data}

Pengumpulan data, penulis mendatangi langsung kantor untuk menemui pimpinan dan meminta ijin menyebarkan kuesioner kepada karyawan yang dijadikan sebagai responden pada penelitian ini dengan mematuhi protokol kesehatan. Selanjutnya melakukan pengukuran variabel yang ditanggapi oleh responden menggunakan skala likert lima poin. Indikator yang digunakan untuk mengukur variabel pokok penelitian adalah kecerdasan emosional (kesadaran diri, pengaturan diri, motivasi diri, kesadaran social, dan keterampilan social), komunikasi interpersonal (keterbukaan, empati, sikap mendukung, sikap positif, dan kesetaraan), kinerja pegawai (kualitas kerja, kuantitas kerja, pengetahuan, kualitas personal, kooperatif, tanggung jawab, dan inisiatif).

Analisis dan pengujian data untuk mengetahui pengaruh antara variabel bebas dan terikat secara parsial maupun simultan, maka alat uji yang digunakan adalah analisis Regresi Linear Berganda (multiple regression) dengan menggunakan statistical package for social scientists (SPSS) sebagai alat uji statistik. Model persamaan regresi linear berganda adalah:

$$
\mathrm{Y}=\alpha+\beta_{1} \mathrm{X}_{1}+\beta_{2} \mathrm{X}_{2}
$$


Keterangan:

$\mathrm{Y} \quad=$ Kinerja karyawan

$\alpha \quad=$ Nilai konstanta

$\beta_{1}, \beta_{2}=$ Koefisien determinasi

$\mathrm{X}_{1}=$ Kecerdasan emosional

$\mathrm{X}_{2} \quad=$ Komunikasi interpersonal

Untuk menguji apakah instrumen yang digunakan memenuhi syarat-syarat alat ukur yang baik, maka digunakan uji validitas dan uji reliabilitas. Hasil uji validitas dan reliabilitas menunjukkan bahwa instrumen yang digunakan telah memenuhi syarat validitas yaitu nilai $\mathrm{r}_{\text {tabel }}$ sebesar 0,361 dan uji reliabilitas diperoleh nilai Cronbach alpha lebih dari 0,6 untuk masing-masing variabel. Selanjutnya adalah uji analisis yang digunakan sebelum melakukan analisis regresi linear berganda dengan menggunakan SPSS sebagai alat uji statistik, maka terlebih dahulu dilakukan pengujian persyaratan analisis dengan uji asumsi klasik regresi. Pertama, uji normalitas dengan alat uji yang dipakai P-Plot menyatakan bahwa hasil penelitian kecerdasan emosional, komunikasi interpersonal, dan kinerja karyawan berada tersebar disekitar garis diagonal dimana data mengarah searah garis diagonal, maka dengan begitu hasilnya sudah terbagi secara normal. Kedua, hasil uji multikolineritas yang telah dilakukan pada tabel 1 bisa diamati kalau skor VIF kecerdasan emosional dan komunikasi interpersonal adalah kurang dari 10, sehingga dapat dikatakan tidak terjadi gejala multikolineritas, dengan tolerance tidak kurang dari 0,1 maka dapat dinyatakan terbebas dari gejala multikolineritas.

Tabel 1

Hasil Uji Multikolineritas

\begin{tabular}{|l|c|c|c|c|}
\hline \multirow{2}{*}{ Model } & \multirow{2}{*}{$\boldsymbol{t}$} & \multirow{2}{*}{ Sig. } & \multicolumn{2}{c|}{ Collinearity Statistics } \\
\cline { 4 - 6 } & & & Tolerance & VIF \\
\hline (Constant) & .974 & .334 & & \\
\hline Kecerdasan Emosional & 2.629 & .011 & .979 & 1.022 \\
\hline Komunikasi Interpersonal & 5.614 & .000 & .979 & 1.022 \\
\hline
\end{tabular}

Sumber: Data diolah, 2021

Ketiga, uji heteroskedastisitas digunakan untuk mengetahui ada atau tidaknya ketidaksamaan varian dari residual pada model regresi. Hasil uji dengan menggunakan SPSS dapat dilihat pada Gambar 2. Berdasarkan Gambar 2. terlihat bahwa tidak ada pola yang jelas serta titik-titik tersebut menyebar diatas dan dibawah angka 0 pada sumbu $Y$. Hal ini menunjukkan bahwa data dalam penelitian ini tidak terjadi heteroskedastisitas.

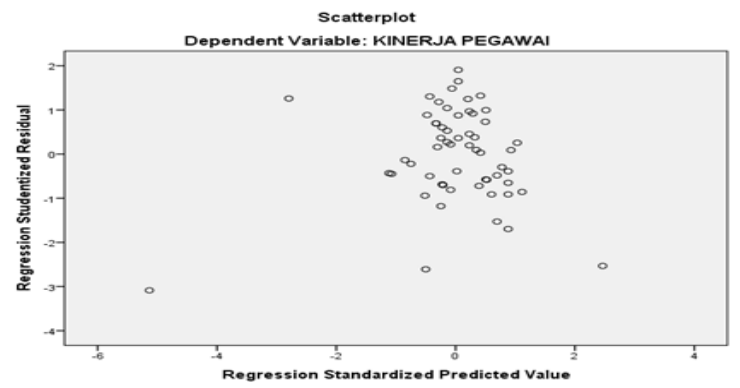

Gambar 2. Hasil Uji Heteroskedastisitas Scatterplot 
Data yang diuji dengan menggunakan uji asumsi klasik telah memenuhi persyaratan yang ditentukan pada kedua uji tersebut.

\section{Hasil Analisis dan Pembahasan}

\subsection{Hasil Analisis}

Komposisi responden berdasarkan aspek jenis kelamin menunjukkan bahwa responden pria merupakan responden yang lebih dominan yaitu $84 \%$ dari total 57 responden. Hal ini menunjukkan bahwa sebagian besar responden adalah jenis kelamin pria. Komposisi menurut usia menunjukkan bahwa responden berusia 19 sampai 32 tahun adalah yang terbesar yaitu $60 \%$ dan disusul karyawan yang berusia 33 sampai 44 tahun sebanyak $12 \%$ dari total 57 responden. Selanjutnya menurut tingkat pendidikan menunjukkan bahwa responden lulusan SMA/SMK merupakan responden mayoritas yaitu 49\% dan lulusan sarjana $21 \%$ dari total 57 responden yang berpartisipasi dalam penelitian ini.

Dalam penelitian ini menggunakan uji $F$ dan uji $t$ untuk menguji hipotesis. Uji $F$ dilakukan untuk mengetahui tingkat signifikansi pengaruh variabel X1 dan X2 secara bersamaan terhadap kinerja karyawan di PT. PLN (Persero) Cabang Ternate. Untuk menguji hipotesis pengaruh variabel independen secara simultan terhadap variabel dependen yaitu dengan cara membandingkan nilai $F_{\text {hitung }}$ dengan nilai yang ada pada $F_{\text {tabel }}$, dengan ketentuan sebagai berikut: Jika $F_{\text {hitung }}>F_{\text {tabel, }}$, maka $\mathrm{H}_{0}$ ditolak; dan Jika $F_{\text {hitung }}<$ $\mathrm{F}_{\text {tabel, }}$ maka $\mathrm{H}_{1}$ ditolak. Berdasarkan hasil perhitungan diperoleh nilai $\mathrm{F}_{\text {hitung }}$ sebesar 21.826 pada tingkat signifikan 0,000 . Dengan menggunakan tingkat kepercayaan $95 \%, \alpha$ $=5 \%$, diperoleh $\mathrm{F}_{\text {tabel }}$ sebesar $=3,16$. Hasil perhitungan menunjukkan nilai $\mathrm{F}_{\text {hitung }}$ pada nilai signifikansi lebih kecil dari 0.05 (0.000), maka keputusan yang diambil adalah menolak $\mathrm{H}_{0}$ dan menerima $\mathrm{H}_{1}$. Hal ini berarti, kecerdasan emosional dan komunikasi interpersonal secara simultan berpengaruh positif dan signifikan terhadap kinerja karyawan di PT. PLN (Persero) Cabang Ternate.

Tabel 2

Hasil Pengujian Regresi Linear Berganda Pengaruh Variabel X1 dan X2 terhadap Kinerja Karyawan

\begin{tabular}{|l|c|c|c|}
\hline \multicolumn{1}{|c|}{ Variabel } & $\boldsymbol{B}$ & $\boldsymbol{t}$ & Sig. \\
\hline 1 (Constant) & 6.759 & .974 & .334 \\
$\begin{array}{l}\text { Kecerdasan } \\
\text { emosional (X1) } \\
\begin{array}{l}\text { Komunikasi } \\
\text { interpersonal (X2) }\end{array}\end{array}$ & .282 & 2.629 & .011 \\
\hline
\end{tabular}

Sumber: Data diolah, 2021

Berdasarkan uji hasil regresi linear berganda pada tabel 2 diatas, menunjukkan bahwa, kecerdasan emosional memiliki nilai thitung 2,629 lebih besar dari nilai $t_{\text {tabel }}$ sebesar 2,00 . Sedangkan nilai signifikansi sebesar 0,011 lebih kecil dari $\alpha=5 \%(0,05)$. Dengan demikian hipotesis yang mengatakan kecerdasan emosional berpengaruh positif dan 
signifikan secara parsial terhadap kinerja karyawan diterima. Selanjutnya, pada tabel 2 juga menunjukkan bahwa, variabel komunikasi interpersonal memiliki nilai $t_{\text {hitung }}$ 5,614 dengan nilai signifikansi sebesar 0,000 lebih kecil dari $\alpha=5 \%(0,05)$. Dengan demikian hipotesis yang menyatakan komunikasi interpersonal berpengaruh positif dan signifikan terhadap kinerja karyawan dapat diterima.

Berdasarkan hasil uji nilai koefisien regresi yang diperoleh pada tabel diatas, maka persamaan regresi yang memperlihatkan hubungan antar variabel bebas terhadap variabel terikat dapat ditulis sebagai berikut:

$$
\mathrm{Y}=6.759+0,282 \mathrm{X}_{1}+0,645 \mathrm{X}_{2}
$$

Persamaan regresi linear berganda diatas menunjukkan bahwa nilai konstanta sebesar 6,759 mengandung arti bahwa kinerja karyawan akan meningkat sebesar 6,759 jika kecerdasan emosional dan komunikasi interpersonal sama dengan nol. Selain itu, analisis ini juga menunjukkan bahwa walaupun variabel kecerdasan emosional dan komunikasi interpersonal yang dimiliki oleh karyawan bernilai zero, tetapi karyawan masih melaksanakan tugas di PT. PLN (Persero) Cabang Ternate.

Selain itu, berdasarkan persamaan regresi linear berganda tersebut diatas dapat dijelaskan bahwa, apabila terjadi peningkatan X1 satu satuan, maka Y pada PT. PLN (Persero) Cabang Ternate akan meningkat sebesar 0,282 jika variabel X2 diasumsikan konstan atau tidak berubah. Sedangkan apabila terjadi peningkatan skor X2 sebesar satu satuan, maka Y akan meningkat sebesar 0,645 jika variabel X1 diasumsikan konstan atau tidak berubah. Selain itu juga, variabel yang dominan berpengaruh terhadap karyawan adalah variabel komunikasi interpersonal karena memiliki nilai koefisien regresi yang besar dari variabel kecerdasan emosional.

Tabel 3

Model Summary

\begin{tabular}{|c|c|c|c|}
\hline$R$ & $R$ Square & $\begin{array}{c}\text { Adjusted } R \\
\text { Square }\end{array}$ & $\begin{array}{c}\text { Std. Error of the } \\
\text { Estimate }\end{array}$ \\
\hline $.669^{\mathrm{a}}$ & .447 & .427 & $\mathbf{3 . 9 2 4 5 4}$ \\
\hline
\end{tabular}

Sumber: Data diolah 2021

Berdasarkan tabel 3 diatas, diperoleh nilai $\mathrm{R}$ sebesar 0,669 atau 66,90\%, yang berarti bahwa terdapat hubungan positif antara kecerdasan emosional dan komunikasi interpersonal dengan kinerja karyawan. Hubungan antar variabel tersebut berada dalam kategori kuat, sebagaimana pendapat Sugiyono (2007), bahwa rentang skor 0,60 - 0,79 berarti hubungan yang kuat sebesar $65,60 \%$. Sementara itu, nilai determinasi $R^{2}(R$ squared) sebesar 0,447 yang berarti bahwa, presentase sumbangan pengaruh variabel kecerdasan emosional dan komunikasi interpersonal terhadap kinerja karyawan di PT. PLN (Persero) Cabang Ternate sebesar 44,70\%, dan sisanya 55,30\% dipengaruhi oleh variabel lain yang tidak diteliti dalam penelitian ini. 


\subsection{Pembahasan}

Hasil pengujian hipotesis pertama menunjukkan bahwa kecerdasan emosional berpengaruh positif terhadap kinerja karyawan pada PT. PLN (Persero) Cabang Ternate. Hasil ini menunjukkan bahwa kecerdasan emosional mampu meningkatkan kinerja karyawan pada PT. PLN (Persero) Cabang Ternate. Hasil pengujian ini berdasarkan nilai $t_{\text {hitung }}$ lebih besar dari nilai $t_{\text {tabel. }}$ Selain itu, sebelumnya telah dideskripsikan secara keseluruhan bahwa para karyawan PT. PLN (Persero) Cabang Ternate telah melakukan penilaian melalui kuesioner terkait dengan kecerdasan emosional. Secara keseluruhan total skor hasil tanggapan menunjukkan bahwa nilai rata-rata skor variabel kecerdasan emosional menunjukkan bahwa seluruh item pernyataan pada variabel ini masuk dalam kategori baik atau tinggi. Dengan kata lain, faktor-faktor kecerdasan emosional memberikan kontribusi positif terhadap kinerja karyawan pada PT. PLN (Persero) Cabang Ternate. Hasil penelitian ini relevan dengan pendapat yang dikemukakan oleh Agustian (2005) berpendapat, bahwa keberadaan kecerdasan emosional yang baik akan membuat karyawan menampilkan kinerja lebih baik. Kecerdasan emosional adalah kemampuan memahami dan mengatur orang lain untuk bertindak bijaksana dalam menjalin hubungan, yang meliputi kecerdasan interpersonal dan kecerdasan intrapersonal. Ini berarti kecerdasan emosional karyawan mampu mendorong mereka untuk melaksanakan tugas demi kepentingan organisasi PT. PLN (Persero) Cabang Ternate.

Berdasarkan pada distribusi tanggapan responden terhadap variabel kecerdasan emosional seluruh item dalam variabel ini tergolong kategori baik atau tinggi, ini dapat dilihat dari nilai rata-rata skor yang diperoleh yaitu sebesar 4,19. Meskipun demikian, terdapat beberapa hal yang perlu diperhatikan oleh PT. PLN (Persero) Cabang Ternate, karena masih ada karyawan yang menyatakan tidak setuju terkait dengan: 1) kemampuan karyawan menggerakkan orang lain ditempat kerja; 2) pengetahuan terhadap mengatasi perbedaan ditempat kerja; 3) kemampaun karyawan dalam memahami cara memecahkan masalah pekerjaan; 4) kemampuan memahami perasaan orang lain; dan 5) kemampuan mengemukakan pendapat disertai dengan alasan.

Berdasarkan uraian-uraian diatas, maka dapat disimpulkan bahwa kecerdasan emosional secara parsial berpengaruh positif dan signifikan terhadap kinerja karyawan dapat dibuktikan dalam penelitian ini. Selain itu, hasil penelitian ini relevan dengan penelitian-penelitian yang dilakukan sebelumnya diantaranya adalah: (Supriadi dan Sefnedi, 2017; Sulistio, Assa, dan Herdiansyah, 2016; dan Sholiha, Sunaryo, dan Priyono, 2017), yang menunjukkan bahwa kecerdasan emosional berpengaruh positif dan signifikan terhadap kinerja karyawan. Hasil pengujian hipotesis kedua menunjukkan bahwa kecerdasan emosional berpengaruh positif terhadap kinerja karyawan pada PT. PLN (Persero) Cabang Ternate. Hasil ini menunjukkan bahwa kecerdasan emosional mampu menciptakan atau meningkatkan kinerja karyawan di PT. PLN (Persero) Cabang Ternate.

Hasil pengujian ini berdasarkan nilai thitung yang lebih besar dari nilai tabel sebesar 1,692. Selain itu, sebelumnya telah dideskripsikan secara keseluruhan bahwa para karyawan pada PT. PLN (Persero) Cabang Ternate telah melakukan penilaian melalui 
kuesioner terkait dengan komunikasi interpersonal. Secara keseluruhan total skor hasil tanggapan menunjukkan bahwa nilai rata-rata skor variabel komunikasi interpersonal sebesar 3,83 menunjukkan bahwa seluruh item pernyataan pada variabel ini masuk dalam kategori baik atau tinggi. Hasil penelitian ini relevan dengan pendapat yang dikemukakan oleh Daryanto (2011), komunikasi antar pribadi atau komunikasi interpersonal dapat terjadi dalam konteks satu komunikator dengan satu komunikan (komunikasi diadik: dua orang) atau satu komunikator dengan dua komunikan (komunikasi triadik: tiga orang). Dengan demikian, ketika dua orang atau lebih berinteraksi pada satu situasi (misalnya tempat kerja), maka akan menempatkan diri mereka sendiri dalam situasi satu sama lain, dan berusaha untuk saling memahami satu sama lain atau dapat terjadi sebaliknya.

Berdasarkan pada distribusi tanggapan responden terhadap variabel kepuasan kerja seluruh item yang masuk dalam variabel ini masuk dalam kategori baik atau tinggi, ini dapat dilihat dari nilai rata-rata skor yang diperoleh yaitu sebesar 3,83. Meskipun demikian, terdapat beberapa hal yang perlu diperhatikan oleh PT. PLN (Persero) Cabang Ternate, karena masih ada karyawan yang tidak setuju terkait dengan: 1) kemampuan karyawan dalam mengambil keputusan yang bersifat akomodatif; 2) kemampaun menunjukkan sikap positif; 3) menghargai keberadaan orang lain; dan 4) kemampuan memahami adanya kepentingan yang berbeda.

Berdasarkan berbagai uraian diatas, maka diketahui bahwa komunikasi interpersonal secara parsial berpengaruh positif dan signifikan terhadap kinerja karyawan dapat dibuktikan dalam penelitian ini baik secara teori maupun fakta-fakta yang ditemukan dan telah dianalisis. Selain itu, Penelitian ini sejalan dengan penelitian yang dilakukan oleh Rusmalinda dan Saputri (2016); Krisnanto dan Pratomo (2017); Aziz dan Suryadi (2017); dan Wahyuni dan Irfani (2018), menunjukkan bahwa komunikasi interpersonal berpengaruh positif dan signifikan terhadap kinerja karyawan.

\section{Simpulan}

Berdasarkan hasil analisis data yang telah diuraikan sebelumnya, maka dapat ditarik kesimpulan bahwa kecerdasan emosional berpengaruh positif dan signifikan terhadap kinerja karyawan. Komunikasi interpersonal memiliki pengaruh positif dan signifikan terhadap kinerja karyawan. Kecerdasan emosional dan komunikasi interpersonal berpengaruh positif dan signifikan secara simultan terhadap kinerja karyawan pada PT. PLN (Persero) Cabang Ternate.

Penelitian ini berkontribusi terhadap pengembangan konsep yang berkaitan dengan kecerdasan emosional, komunikasi interpersonal, dan kinerja pegawai jika diterapkan pada Badan Usaha Milik Negara yang menguasai hajat hidup orang banyak. Temuan hasil penelitian yang diuji adalah signifikan, dengan demikian dapat dikatakan bahwa variabel yang diuji merupakan variabel multidimensional didalam teori manajemen sumber daya manusia terbukti secara empiris memiliki dampak terhadap peningkatan kinerja pegawai. Perusahaan diharapkan mampu melakukan penyesuaian-penyesuaian dengan pola kerja yang mendorong kecerdasan emosional dan komunikasi interpersonal. 


\section{Referensi}

Agustian. (2005). Rahasia Sukses Membangun Kecerdasan Emosi dan Spritual ESQ (A. Ginanjar (ed). Arga.

Alkahtani, A. (2013). Employee Emotional Intelligence and Employee Performance in the Higher Education Institutions in Saudi Arabia: A Proposed Theoretical Framework. International Journal of Business and Social Science, 4(9).

Amstrong. (2010). Human Resource Management Practice a Guide to People Management (Michael (ed.)). Kogan Page Limited.

Aziz, F., dan Suryadi, E. (2017). Pengaruh Budaya Organisasi dan Komunikasi Interpersonal Terhadap Kinerja Pegawai di Biroumum Kementerian Pendidikan dan Kebudayaan Republik Indonesia. Jurnal Pendidikan Manajemen Perkantoran, 2(2), 178-187.

Christina, A., dan Samanta, I. (2016). The Impact of Emotional Intelliegence Onimproving Team-Working: The Case of Publik Sector (National Centre for Publikadministration and Local Government- N.C.P.A.L.G). Procedia-Social and Behavioral Sciences., 230, 167-175.

Daft. (2006). Management. Terjemahan oleh Diana Angelica. Salemba Empat.

Daryanto. (2011). Ilmu Komunikasi I. PT Sarana Tutorial Nurani.

Goleman, D. (2009). Kecerdasan Emosional : Mengapa EI Lebih Penting dari pada IQ. PT Gramedia Pustaka Utama.

Krisnanto, I., dan Pratomo, A. (2017). Pengaruh Komunikasi Interpersonal Terhadap Kinerja Karyawan Front Desk Hotel Bumi Senyiur Samarinda. Jurnal Sains Terapan Pariwisata, 2(3), 222-230.

Mangkunegara, A. P. (2000). Manajemen Sumber Daya Manusia Perusahaan (Cetakan ke). PT Remaja Rosda Karya.

Mulyana, D. (2014). Ilmu Komunikasi: Suatu Pengantar (Cetakan ke). PT Remaja Rosdakarya.

Pasolong, H. (2010). Teori Administrasi Publik (Cetakan ke). Alfabeta.

Putra. (2012). New Public Governance (Fadhila (ed.)). Universitas Brawijaya Press.

Putri, G., O. (2018). Inovasi Pelayanan Bagi Anak Penyandang Autis (Studi pada Program Pelayanan Anak Autis di Pusat Layanan Autis Kota Blitar). Universitas Muhammadiyah Malang.

Robbins, S., P., dan Judge, T., A. (2013). Organizational Behavior 15th ed. New Jersey: Pearson Education. Inc.

Rusdi, F., Langkai, J., dan Tangkau, C., H. (2020). Civil Servants'Competence as Public Service. SEIKO Journal of Management and Busniness, 3(2), 114-123.

Rusmalinda., S dan Saputri, M., E. (2016). Pengaruh Komunikasi Interpersonal Terhadap Kinerja Karyawan di Lembaga Bimbingan dan Konsultasi Belajar Prestise. Journal E-Proceeding of Management, 3(1), 1-5.

Salovey, P., dan Mayer, J., D. (1990). Emotional Intelligence. Jurnal Imagination, 
Cognition and Personality, 9(3), 185-211.

Sefnedi, S. dan. (2017). The Effect of Emotional Intelligence and Organizational Cynicism on Job Performance: The Role of Motivation as Mediator. Journal of Business and Management (IOSR-JBM), 19(3), 101-107.

Sholiha, M., Sunaryo, H., dan Priyono, A., A. (2017). Pengaruh Kecerdasan Emosional dan Kecerdasan Spiritual Terhadap Kinerja Guru SMP An-Nur Bululawang. Jurnal Warta Ekonomi, 7(17), 78-92.

Sulistio, H., Assa, A., F., dan Herdiansyah, I., M. (2016). Pengaruh Kecerdasan Emosional dan Kepribadian Terhadap Kinerja Karyawan pada PT Bank Danamon Indonesia, TBK. Jurnal Manajemen Bisnis - Kompetensi, 11(1), 41-48.

Wahyuni, R., dan Irfani, H. (2018). Pengaruh Komunikasi Interpersonal Terhadap Kinerja Pegawai dengan Komitmen Organisasi sebagai Variabel Moderating (Studi pada Pegawai RSUP Dr. M. Djamil Padang). Jurnal PSYCHE, 11(2).

Widyastini, E. (2003). EQ dan Kesuksesan Kerja.

Yusni, M., A. (2015). Studi Tentang Pelayanan Haji di Kementrian Agama Kota Samarinda. EJournal Ilmu Pemerintahan, 3(1), 318-332. 